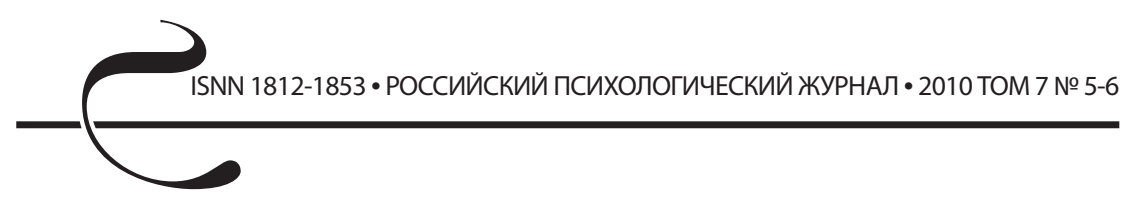

\author{
Самойлина Т.Г., Середина Н.В. \\ Содержание представлений о террористе \\ и террористической угрозе у жителей \\ разных регионов Южного федерального округа РФ
}

В статье представлен анализ проблемы современного терроризма, представлений о террористах как исполнителе террористического акта. Приводится авторская методика-опросник «Оиенка террористической угрозы», структурно состоящий из трех блоков: психологическое содержание представлений о террористе; представление о террористическом акте, местах совершения и способах его избежания; представления о поведении заложников и собственном поведении опрашиваемого в случае захвата. Приводятся результаты исследования, проведенного с помощью авторского опросника в разных регионах Южного федерального округа.

Ключевые слова: террорист, террористический акт, заложники, облик террориста, цели преступлений террористов, угроза теракта.

Проблема терроризма в современном обществе приобрела небывалую остроту. Хотя корни терроризма как политического и социального явления уходят в прошлые века, его постоянно меняющиеся формы складывают отношение к нему как к феномену исключительно новому, присущему современному обществу. Формированию этого представления способствует и тот факт, что методы терроризма становятся все более изощренными и разрушительными, а его распространение приобретает поистине угрожающий характер $[1,3,6]$.

Характерными чертами современного терроризма является его направленность против мирного населения. Поэтому совершение террористических актов происходит, главным образом, в местах массового скопления людей наиболее опасным способом, что приводит к большому количеству жертв, в числе которых находятся женщины и дети. Все это вызывает мощный общественный резонанс и рост социальной напряженности в обществе $[6,8,10]$.

Для предотвращения террористических актов Правительством РФ были приняты Законодательные акты, подписаны международные Конвенции о борьбе с терроризмом [9].

Однако для борьбы с таким многоаспектным и сложным явлением как терроризм, одних только правовых и политических мер недостаточно. Необходимо учитывать также социальный и психологический аспекты, требующие всестороннего и глубокого изучения.

Анализ литературных источников позволяет сделать вывод, что в настоящее время проблема терроризма в России исследована достаточно широко с точки зрения политического, правового, экономического, социального, культурно-религиозного подходов. Тем не менее, до сих пор недостаточно изучено представление, складывающееся в разных группах населения о террористах и террористическом акте, 
слабо разработаны рекомендации действий в случае совершения террористического акта, отсутствует должная система подготовки специалистов, предназначенных для проведения переговоров с террористами. Вместе с тем, решение указанного круга вопросов становится все острей $[3,5,6,10]$.

С целью изучения психологического содержания представлений о террористе, а также оценки угрозы террористического акта были обследованы жители различных регионов Южного федерального округа Российской Федерации. Обследование проводилось с помощью опросника «Оценка террористической угрозы» (Н.В. Серединой, Т.Г. Самойлиной)

\section{Описание методики}

Методика представляет собой опросник, состоящий из двадцати открытых вопросов, на которые опрашиваемый дает ответы в свободной форме.

Опросник структурно представлен тремя блоками:

1. Психологическое содержание представлений о террористе.

2. Представления о террористическом акте, местах совершения и способах его избежания.

3. Представления о поведении заложников и собственном поведении опрашиваемого в случае захвата.

\section{Рекомендации по проведению исследования с помощью опросника «Оценка террористической угрозы»}

Опрос проводится анонимно. Для получения оптимальных результатов исследование желательно проводить в индивидуальной форме. В случае проведения опроса в группе следует обеспечить самостоятельность ответов, поскольку наибольшую ценность для исследования представляет индивидуальное мнение каждого.

\section{Инструкция испытуемым}

«Просим Вас ответить на вопросы, оценивающие уровень террористической угрозы для Вас и Ваших близких в настоящее время. Нас интересует именно Ваше мнение по каждому из предлагаемых вопросов. Благодарим Вас за участие в исследовании».

Ваш пол__ Возраст
Город/Населенный пункт Род занятий

1. Как выглядит террорист? Опишите его внешность.

2. Какова национальная принадлежность террориста?

3. Какого он пола? Возраста?

4. Каково социальное положение (семейное положение, материальный, образовательный, профессиональный уровень) террориста?

5. Каковы религиозные убеждения террориста?

6. Какими чертами характера обладает террорист? 
7. Как террорист относится к другим к людям?

8. Каковы моральные ценности и идеалы террориста?

9. Как террорист относится к самому себе?

10.Что побуждает террориста совершить теракт?

11.Чем террорист может отличаться от других людей в толпе?

12.В каких местах вашего города может произойти теракт?

13.Как нужно вести себя при теракте?

14.Как могут вести себя заложники в случае захвата?

15.Какие действия заложника могут сохранить ему жизнь?

16.Есть ли шансы у заложника остаться в живых?

17.Угрожает ли Вам терроризм или Вы считаете, что это явление Вас никогда не коснется?

18.Может ли теракт когда-нибудь коснуться ваших близких и родных?

19.Как можно сегодня предотвратить террористические акты?

20.Какие действия следует предпринять, чтобы избежать теракта?

Предварительный анализ полученных результатов показал следующее.

Отличительной чертой во внешности террориста респонденты называют его небритость (40 \%), атлетическое телосложение (33\%) и преимущественно черную одежду (20\%).

Из числа опрошенных респондентов 33 \% отметили, что террорист может выглядеть как любой мирный гражданин, т.е. неотличим в толпе. Остальные респонденты считают, что террориста можно в толпе отличить по внешним особенностям: $40 \%$ респондентов отметили, что террорист в толпе отличается недобрым взглядом, 27\% опрошенных отметили, что террориста в толпе можно узнать по особенностям его поведения, $10 \%$ - по напряженности и скованности, $17 \%$ - по особой обеспокоенности.

На вопрос о национальности террориста были получены следующие ответы: $60 \%$ респондентов указали на то, что террорист может быть любой национальности, 26 \% опрошенных считают, что террорист может быть, скорее всего, кавказец, 14 \% респондентов относят террориста к чеченской национальности.

Относительно половой принадлежности 86 \% опрошенных указали, что террорист будет мужского пола, $24 \%$ - женского.

По мнению 56 \% респондентов, вероисповеданием террориста является ислам, $44 \%$ обследуемых ответили, что террорист далек от истинной религии.

Ответы респондентов на вопросы о других социально-демографических характеристиках террориста распределились следующим образом: у террориста низкое материальное положение (53\%), низкий образовательный (50 \%) и низкий профессиональный (43\%) уровень.

Психологическая характеристика террориста, по мнению опрошенных, выглядит следующим образом: 56 \% респондентов среди черт характера террориста выделили жестокость, 17 \% отметили решительность, 13 \% отмечают, что террорист, скорее всего, будет страдать некоторыми психическими расстройствами. 
Большинство опрошенных (67 \%) считают, что террористу присущ выраженный фанатизм, 52 \% - жестокость, а $26 \%$ респондентов наделяют террориста некоторой одержимостью.

По мнению 63 \% респондентов, террорист негативно относится к другим людям, он высокомерен, считает других ниже себя, 43 \% респондентов отметили, что террорист, скорее всего, безразличен к другим людям, которые лишь являются средством для достижения террористом своих целей, 40 \% респондентов считают, что окружающий мир террорист видит враждебным и нуждающимся в изменениях.

С точки зрения респондентов целями преступлений террористов являются: выдвижение политических требований (56 \%), обогащение (43\%), религиозные убеждения (36\%), уничтожение и запугивание мирных граждан (30\%).

С точки зрения респондентов террористический акт заключается: во взрывах (30 \%), в уничтожении мирного населения (56 \%), в захвате заложников (30\%).

По мнению респондентов всех обследованных регионов Южного федерального округа РФ, террористы, либо имеют искаженные моральные ценности (жажда крови, жажда наживы, религиозный фанатизм и др.), либо вообще не имеют таковых.

По мнению опрошенных респондентов, террориста побуждает совершить теракт внушенное ему убеждение, что он попадет в рай, нужда и безысходность, воздействие наркотиков, психическое воздействие («зомбирование»), принуждение к свершению террористических действий с помощью угроз, несправедливость государственного строя, обида на весь мир и деньги.

На вопрос «Угрожает ли вам террористический акт?» $98 \%$ респондентов республики Дагестан дали ответ «да, угрожает». Причем 18 \% из их числа связывают эту угрозу с пребыванием в республике: «угрожает, пока я в Дагестане». 7 \% жителей Дагестанской республики при ответе на этот вопрос отметили, что они реально находились в ситуации угрозы теракта, избежать которого «удалось лишь по счастливой случайности». Угрозу для своих близких отмечают $97 \%$ респондентов республики Дагестан, и только 3 \% такой угрозы для своих близких не видят.

Bсе 100 \% опрошенных жителей Северной Осетии полагают, что для них существует угроза теракта, а 90 \% не исключают угрозы терроризма для их родных и близких.

$95 \%$ респондентов Кабардино-Балкарии считают, что теракт может коснуться их близких или уже коснулся, и только 5 \% уверены, что этого не случится. Только 5 \% респондентов Кабардино-Балкарии полагает, что теракт им не угрожает, остальные $95 \%$ считают, что угрожает, или надеются, что это их не коснется.

$54 \%$ респондента Чеченской республики, ответили, что терроризм может коснуться каждого ее жителя, 57 \% надеются, что теракт не коснется их родных и близких и только 11,5 \% уверены, что терроризм им не угрожает.

Таким образом, обобщенное представление респондентов о террористе включает следующие характеристики. Террорист - это скрытный человек кавказской или любой другой национальности, негативно относящийся к другим людям, имеющий искаженные моральные ценности и религиозные идеалы, с низким 
образовательным, профессиональным и материальным уровнем, поведением которого движет фанатизм.

В настоящее время исследование проблемы террористической угрозы в разных регионах Южного федерального округа РФ продолжается.

\section{Литература}

1. Антонян Ю.М. Терроризм. Криминологическое и уголовно-правовое исследование. - М.: Изд-во «Щит», 2001.

2. Асанов Е.В. Роль права в предотвращении межнациональных конфликтов. Межнациональные конфликты. Место и роль органов внутренних дел в межнациональных конфликтах - М.: Изд-во Академия МВД России, 1992.

3. Афонин С.А. и др. Современный терроризм и борьба с ним: социальногуманитарные измерения / под ред В.В. Ященко. - М.: МЦНМО, 2007.

4. Самойлина Т.Г., Середина Н.В., Нурмамедова Д.Ш. Психологические особенности образа террориста в различных социальных группах / Материалы научно-практической конференции «Противодействие идеологии экстремизма и терроризма в рамках реализации государственной молодежной политики». Ростов-на-Дону, 12-14 октября 2009 года - Вып. 1. - М.: Изд-во КРЕДО, 2009.

5. Соболев В. Противодействовать идеологии терроризма // ИТАР-ТАСС. 24.06.2009.

6. Современный политический экстремизм / под ред. Н.З. Дибирова, Г.К. Сафаралиева. - Махачкала: Изд-во Лотос, 2009. - 640 с.

7. Сочивко Д.В. и др. Подсознание террориста. - М.: Изд-во ПЕР СЭ, 2006.

8. Терроризм в России и проблемы системного реагирования / под ред. А.И. Долговой. - М., 2004.

9. Терроризм. Правовые аспекты борьбы. Нормативные и международные правовые акты с комментариями. Научные статьи / отв. ред. и рук. авт. коллектива И.Л. Трунов. - М.: Изд-во Эксмо, 2005.

10. Устинов В.В. Международный опыт борьбы с терроризмом: стандарты и практика. - М.: Изд-во Юрилитинформ, 2002. 